\title{
Nicotinic receptor modulation to treat alcohol and drug dependence
}

\author{
Shafiqur Rahman ${ }^{1 *}$, Eric A. Engleman ${ }^{2}$ and Richard L. Bell ${ }^{2}$ \\ Department of Pharmaceutical Sciences, College of Pharmacy, South Dakota State University, Brookings, SD, USA \\ 2 Department of Psychiatry, Institute of Psychiatric Research, Indiana University School of Medicine, Indianapolis, IN, USA
}

\section{Edited by:}

Youssef Sari, University of Toledo, USA

\section{Reviewed by:}

Esa R. Korpi, University of Helsinki,

Finland

Sara Morley-Fletcher,

CNRS-University Lille, France

*Correspondence:

Shafiqur Rahman, Department of Pharmaceutical Sciences, Avera

Health and Science Center, College of Pharmacy, South Dakota State

University, Box 2202C, SAV 265,

Brookings, SD 57007, USA

e-mail:shafiqur.rahman@

sdstate.edu
Alcohol and drug dependence are serious public health problems worldwide. The prevalence of alcohol and drug dependence in the United States and other parts of the world is significant. Given the limitations in the efficacy of current pharmacotherapies to treat these disorders, research in developing alternative pharmacotherapies continues. Preclinical and clinical evidence thus far has indicated that brain nicotinic acetylcholine receptors (nAChRs) are important pharmacological targets for the development of medications to treat alcohol and drug dependence. The nAChRs are a super family of ligand gated ion channels, and are expressed throughout the brain with twelve neuronal nAChR subunits $(\alpha 2-\alpha 10$ and $\beta 2-\beta 4)$ identified. Here, we review preclinical and clinical evidence involving a number of $n A C h R$ ligands that target different $n A C h R$ subtypes in alcohol and nicotine addiction. The important ligands include cytisine, lobeline, mecamylamine, varenicline, sazetidine $A$ and others that target $\alpha 4 \beta 2^{*}$ nAChR subtypes as small molecule modulators of the brain nicotinic cholinergic system are also discussed. Taken together, both preclinical and clinical data exist that support nAChR-based ligands as promising therapeutic agents for the treatment of alcohol and drug dependence.

Keywords: nicotinic receptor, alcohol dependence, nicotine addiction, drug addiction, CNS disorders, drug development, animal models

\section{OVERVIEW-ALCOHOL AND DRUG DEPENDENCE: NICOTINIC RECEPTORS}

Alcohol and drug dependence are chronic neuropsychiatric and relapsing disorders and represent a significant public health problem worldwide (Koob and Volkow, 2010; Volkow and Baler, 2014; Wise and Koob, 2014). Furthermore, fetal alcohol syndrome caused by alcohol exposure in utero is the number one preventable cause of cognitive and attentional deficits (Niccols, 2007; Leibson et al., 2014). The prevalence of alcohol abuse and dependence in the United States is about $8.5 \%$ with an estimated annual cost of 185 billion dollars (Litten et al., 2012; Davies et al., 2013). In addition, due to limited efficacy with existing US Food and Drug Administration (FDA)-approved medications for alcohol dependence, such as naltrexone and acamprosate, and high relapse rates, there is a need for alternative brain targets (Volkow and Skolnick, 2012). These brain targets will open new avenues for better treatment strategies targeting alcohol or drug dependence by interrupting the dependence and relapse cycle. The current review aims to cover the currently available pharmacological and therapeutic approaches involving nicotinic acetylcholine receptors (nAChRs) relevant to alcohol and drug dependence. In addition, this review will discuss the current status, putative mechanisms of action, and future directions for research into cholinergic treatments targeting alcohol and drug dependence. We believe molecular targets within the nAChR system offer great potential for developing pharmacotherapies to treat alcohol dependence and other addictive disorders. Moreover, neural circuits regulating cognitive activities such as decision-making and associated behaviors are negatively impacted by chronic alcohol or nicotine exposure (Clark and Robbins, 2002; Noël et al., 2013). Therefore, potential use of nAChR-based ligands and their ability to reverse some of these negative effects could improve impaired cognitive function of alcoholics and addicts and enhance the effectiveness of cognitive and behavioral therapies (Chatterjee and Bartlett, 2010).

A role for brain, ligand-gated, membrane bound ion channelassociated nAChRs in alcohol and drug dependence has been well-documented (see Feduccia et al., 2012; Rahman and Prendergast, 2012; Rahman, 2013; Hendrickson et al., 2013). The nAChRs are ionotropic or ligand-gated ion channels which belong to a superfamily of homologous receptors including glycine, serotonin type 3 (5-HT3), and $\gamma$-amino butyric acid (GABA) receptors (Dani and Bertrand, 2007; Hurst et al., 2013). The nAChRs in the mammalian central nervous system regulate processes such as neurotransmitter release, cell excitability, and neuronal integration and influence physiological functions, including arousal, sleep, mood, pain, and cognition (Klink et al., 2001; Hogg et al., 2003; Albuquerque et al., 2009; Gotti et al., 2009). The nAChR ion channel is formed by five membranespanning subunits which allow passage of cations like $\mathrm{Na}^{+}$and $\mathrm{Ca}^{++}$. Each subunit has a long extracellular hydrophilic Nterminus containing the ligand binding domain, four hydrophobic transmembrane domains (TM1-TM4), and a short carboxy terminus facing the extracellular surface (Champtiaux et al., 2003; Albuquerque et al., 2009). The TM2 domain forms the inner lining of the cation channel and the anionic amino acids in this 
domain regulate ion conductance through the pore. The brain $\mathrm{nAChR}$ subunits are classified as alpha $(\alpha 2-\alpha 10)$ or beta $(\beta 2-\beta 4)$, according to the protein sequence and presence in the $\mathrm{N}$-terminal domain of the $\alpha$-subunits of two adjacent cysteines at positions 192 and 193, which are thought to participate in the ligand binding site. While the residues in the $\alpha$-subunit form the primary face of the agonist binding site and determine the affinity for the ligand, the $\beta$-subunit forms the complementary face of the binding site and contributes to ligand selectivity (Gotti et al., 2009). Heteromeric receptors are assembled from both alpha $(\alpha 2-\alpha 6)$ and beta subunits, while homomeric receptors are formed by alpha subunits only. Thus, heteromeric nAChRs contain two ligand binding sites (at the interface of $\alpha$ and $\beta$ subunits), whereas homomeric nAChRs contain five ligand binding sites.

The nAChRs with identical subunit composition may differ in the stoichiometry of subunits, thus contributing to the variable channel kinetics, agonist binding, and pharmacological heterogeneity of nAChRs (Champtiaux et al., 2003; Moroni and Bermudez, 2006; Millar and Gotti, 2009). For example, $(\alpha 4)_{2}(\beta)_{3}$ $\mathrm{nAChR}$ subtypes are more sensitive (show higher affinity) to agonists in comparison to low affinity $(\alpha 4)_{3}(\beta)_{2}$ subtypes, indicating that changes in nAChR stoichiometry can elicit different physiological and pharmacological responses (Nelson et al., 2003). More than $90 \%$ of the receptor subtypes in the rodent brain are $\alpha 4 \beta 2$ nAChRs (Flores et al., 1992; Gotti et al., 2007; Albuquerque et al., 2009). However, the $\beta 2$ subunit is less ubiquitous in the human brain (Paterson and Nordberg, 2000). The $\alpha 4 \beta 2 \mathrm{nAChRs}$ are widely distributed in various neuroanatomical regions, including the mesocorticolimbic dopamine system (Perry et al., 2002; Zoli et al., 2002; Gotti et al., 2007, 2009, see Table 1). The $\alpha 7$ nAChRs are also highly expressed in the brain and predominantly located in the hippocampus, cortex, and subcortical limbic regions (Gotti et al., 2007, 2009, see Table 1). Previous studies suggest that nAChRs are expressed at the synapse, cell body, and

Table 1 | Localization of brain nAChR subtypes (heteromeric ${ }^{1}$ and homomeric ${ }^{2}$.

\begin{tabular}{ll}
\hline Prefrontal cortex & $\alpha 4 \beta 2^{* a, b}, \alpha 7^{c, d}$ \\
Ventral tegmental area & $\alpha 4 \beta 2^{* a, b}, \alpha 6 \beta 2^{*} \alpha 3 \beta 4^{*}, \alpha 7^{c, d}$ \\
Nucleus accumbens & $\alpha 4 \beta 2^{* a, b}, \alpha 6 \beta 2^{*} \alpha 3 \beta 4^{*}, \alpha 6 \alpha 4 \beta 2^{*}$ \\
Hippocampus & $\alpha 7^{\mathrm{c}, \mathrm{d}}, \alpha 4 \alpha 5 \beta 2, \alpha 4 \beta 2^{\mathrm{a}, \mathrm{b}}$ \\
Amygdala & $\alpha 4 \beta 2^{* a, b}, \alpha 7^{\mathrm{c}, \mathrm{d}}$ \\
\hline
\end{tabular}

*Indicates other $\alpha$ or $\beta$ subunits such as $\alpha 3, \alpha 5$ or $\alpha 6$ and $\beta 3$ or $\beta 4$.

${ }^{a}$ ACh and nicotine are agonists of $\alpha 4 \beta 2^{*}$ subtype ${ }^{3}$.

${ }^{b}$ Dihydro- $\beta$-erythroidine and mecamylamine are antagonist of $\alpha 4 \beta 2^{*}$ subtype ${ }^{4}$.

${ }^{c}$ ACh, nicotine and choline are agonists of $\alpha 7$ subtype ${ }^{5}$.

${ }^{d} \alpha$-bungarotoxin, mecamylamine, methylylcoconitine and conotoxin are antagonist of $\alpha 7$ subtype ${ }^{6}$.

${ }^{1}$ Flores et al., 1992; Zoli et al., 1998; Paterson and Nordberg, 2000; Perry et al., 2002; Gotti et al., 2007, 2009; Albuquerque et al., 2009.

${ }^{2}$ Gotti et al., 2007, 2009.

${ }^{3}$ Quick and Lester, 2002; Champtiaux et al., 2003; Nelson et al., 2003; Moroni and Bermudez, 2006; Gotti et al., 2007, 2009.

${ }^{4}$ Larsson and Engel, 2004; Gotti et al., 2007, 2009.

${ }^{5}$ Wooltorton et al., 2003; Gotti et al., 2007, 2009.

${ }^{6}$ Gotti et al., 2007, 2009; Kamens et al., 2010; Crooks et al., 2014. axons (Livingstone and Wonnacott, 2009). Presynaptic nAChRs are involved in regulating the release of ACh (Wilkie et al., 1993), NE (Clarke and Reuben, 1996), dopamine (Grady et al., 1992), glutamate (Alkondon et al., 1997), and GABA (Yang et al., 1996). Evidence indicates that dopamine release is modulated by $\alpha 4 \beta 2^{*}$, $\alpha 3 \beta 2^{*}$, and $\alpha 6^{*} \mathrm{nAChRs}$ ( ${ }^{*}$ indicates possible involvement of other receptor subunits) in nigrostriatal terminals (Le Novere et al., 1996; Luo et al., 1998; Wonnacott et al., 2000; Salminen et al., 2004). Glutamate release is regulated by presynaptic $\alpha 7 \mathrm{nAChRs}$ (Mansvelder et al., 2002). Similar to other ligand-gated ion channels, nAChRs modulate the flow of ions across the cell membrane under the influence of an extracellular signaling molecule. A net influx of cations $\left(\mathrm{Na}^{+}, \mathrm{Ca}^{++}\right)$through the ion channel depolarizes the cell membrane and increases neuronal excitability. The $\mathrm{Ca}^{++}$entry through some nAChRs exerts additional effects on intracellular signaling cascades. ACh, the endogenous ligand of nAChRs, is released from the presynaptic cholinergic axon terminals and binds to the extracellular ligand binding domain of the receptor. Binding of ACh or exogenous ligands to the orthosteric site influences transition rates between three distinct functional states of nAChRs: the resting, open, and desensitized states. The rate constants between the functional states are dependent on the specific combination of subunits and the chemical characteristics of the ligand that is bound. Prolonged exposure to small doses of nicotine rapidly activates nAChRs initially, which is followed by desensitization of various $\mathrm{nAChR}$ subtypes (Quick and Lester, 2002). Heteromeric subtypes such as $\alpha 4 \beta 2^{*}$ or $\alpha 6 \beta 2^{*}$ slowly desensitize in an activity-dependent manner when exposed to low concentrations of nicotine, whereas homomeric subtypes such as $\alpha 7^{*}$ nAChRs are much less susceptible to desensitization (Wooltorton et al., 2003) to low concentration of nicotine. The nAChR subtypes are stimulated or blocked by a number of agonists or antagonists (Gotti et al., 2007, 2009, see Table 1). Furthermore, brain nAChRs can be desensitized by continuous or repeated exposure to an agonist (e.g., nicotine) that results in progressive decreases in response to the drug. However, antagonism produced by specific ligand binding to the nAChR is somewhat different pharmacologically from these desensitized states (Buccafusco et al., 2009).

Recent work with nAChR subtype knockout $(\mathrm{KO})$ mice have provided important information on both brain nAChR function and their mediation of addiction related behavior (Fowler et al., 2008; Mineur and Picciotto, 2008; Changeux, 2010). For example, early research showed that mice lacking the $\beta 2$ subunit do not display several nicotine-associated responses, including nicotine-induced DA release in the dorsal and ventral striatum as well as, nicotine-elicited increases in the firing rate of associated DA neurons (Picciotto et al., 1995, 1998). The lack of nicotine's effect on the mesolimbic DA systems in $\beta 2$ subtype $\mathrm{nAChR} \mathrm{KO}$ mice is consistent with the absence of nicotine selfadministration by these animals (Picciotto et al., 1998). The $\alpha 4$ subunit requires the $\beta 2$ subunit for assembly in the majority of heteromeric nAChRs in the brain, these and other studies using genetically modified mice suggest that $\alpha 4 / \beta 2^{*}$ nAChRs are critical for nicotine-related reward behaviors (Ross et al., 2000; Tapper et al., 2004). Despite the distribution of the $\alpha 7$ subunit in the brain, in particular its presence in the mesocorticolimbic 
system, studies in $\alpha 7 \mathrm{KO}$ mice are not definitive about a role for the $\alpha 7$ subunit in nicotine reward and conditioning (Mineur and Picciotto, 2008). However, $\alpha 7^{*} \mathrm{nAChRs}$ are important for long-term potentiation, neuroplasticity associated with learning and memory, in the mesolimbic reward pathway (Mineur and Picciotto, 2008). KO mouse studies targeting the $\alpha 6$ subunit indicate that $\alpha 6$ partners with $\beta 2 \mathrm{nAChRs}$ and may play an important role in nicotine addiction related behavior (Champtiaux et al., 2002). Recently, studies with transgenic over expression of the $\alpha 5$, $\alpha 3$, and $\beta 4$ receptor subunit genes indicate these subunits have a potential, but complex, role in the modulation of nicotine related behaviors (Gallego et al., 2012).

Similar to research on the involvement of AChR subunits in nicotine-induced behaviors, a number of genetic studies have been conducted to identify the role of nAChR subtypes in alcohol drinking behavior. For example, acute alcohol drinking behavior is reduced in $\alpha 4 \mathrm{KO}$ mice compared to wild type (WT) indicating a role for the $\mathrm{nAChR} \alpha 4^{*}$ subunit in alcohol abuse (Hendrickson et al., 2010, 2013). Similarly, alcohol-related behaviors and alcohol-induced midbrain dopaminergic function is decreased in $\alpha 4 \mathrm{KO}$ mice (Liu et al., 2013). On the other hand, $\beta 2 \mathrm{KO}$ mice behave similarly to WT type mice in alcohol drinking behaviors (Kamens et al., 2010). In addition, $\alpha 6 \mathrm{KO}$ and $\beta 3$ $\mathrm{KO}$ mice also display alcohol drinking behavior that is similar to WT mice in a two-bottle alcohol drinking paradigm (Kamens et al., 2010). Moreover, $\alpha 7 \mathrm{KO}$ and WT mice consume similar amounts of alcohol, although there was a potential gender effect regarding $\alpha 7 \mathrm{nAChRs}$ effects on ethanol consumption (Kamens et al., 2010). And, again, $\alpha 5 \mathrm{KO}$ mice do not differ in acute ethanol consumption compared to WT mice (Santos et al., 2012). Like nicotine-related behavior (see above), studies with transgenic over expression of the $\alpha 5, \alpha 3$, and $\beta 4$ receptor subunit genes indicate these subunits have a complex role in the modulation of alcohol related behaviors (Gallego et al., 2012). Together, these data indicate that nAChRs containing $\alpha 5, \alpha 6, \beta 2$, or $\beta 3$ subunits may not be critical in alcohol drinking behaviors. Overall, the evidence indicates that $\alpha 4$ receptors in the midbrain may be associated with alcohol related behavior. Taken together, brain nAChRs represent a diverse class of receptor subtypes which are involved in a number of neurobiological functions and are associated with neurological and psychiatric disorders, including nicotine and alcohol dependence.

\section{NICOTINIC RECEPTORS: TARGETS TO TREAT ALCOHOL DEPENDENCE}

As with the treatment of alcohol dependence, the existing FDAapproved medications for nicotine dependence such as bupropion and varenicline, have had limited efficacy with continued significant relapse rates (Volkow and Skolnick, 2012). These brain targets will open new avenues for better treatment strategies targeting alcohol or drug dependence by interrupting the dependence and relapse cycle. Research indicates that brain $\mathrm{nAChR}$ subtypes are important mediators of the rewarding effects of alcohol (ethanol) and drugs of abuse (Blomqvist et al., 1993; Ericson et al., 1998; Lê et al., 2000; Soderpalm et al., 2000; Chi and de Wit, 2003; Young et al., 2005; Reus et al., 2007; Steensland et al., 2007; Bell et al., 2009; Liu et al., 2013). It is widely known that systemic or local administration of mecamylamine, a non-selective $\mathrm{nAChR}$ antagonist reduces ethanol drinking in a number of animal models (Ericson et al., 1998; Lê et al., 2000; Soderpalm et al., 2000; Steensland et al., 2007). Also, it has been proposed that nAChRs in the VTA regulate ethanol consumption and associated mesocorticolimbic neurochemical effects (e.g., dopamine release) in various animal models (Ericson et al., 1998; Chi and de Wit, 2003). However, mecamylamine either reduces or fails to decrease ethanol drinking behavior in humans (Blomqvist et al., 1996, 2002; Young et al., 2005), indicating mixed efficacy for treating ethanol dependence through nAChR blockade. Understandably, these mixed results have limited mecamylamine's clinical utility for ethanol drinking cessation. On the other hand, a selective $\alpha 4 \beta 2$ antagonist, dihydro- $\beta$-erythroidine failed to suppress ethanol consumption, thus suggesting a role for $\alpha 6 \beta 2^{*}$ but not the $\alpha 4 \beta 2 *$ subtypes in alcohol reinforcement (Larsson et al., 2002; Larsson and Engel, 2004). Similarly, the $\alpha 7 \mathrm{nAChR}$ antagonist methyllycaconitine was ineffective in reducing ethanol intake in an animal model of excessive ethanol drinking (Kamens et al., 2010). Varenicline, a partial $\alpha 4 \beta 2^{*}$ nAChR agonist and FDAapproved medication for smoking cessation (Reus et al., 2007), was found to reduce alcohol drinking in both animal models and humans (Steensland et al., 2007; McKee et al., 2009, 2013; Hendrickson et al., 2010; Kamens et al., 2010; Bito-Onon et al., 2011; Chatterjee et al., 2011; Sajja and Rahman, 2011, 2013a; Mitchell et al., 2012; Litten et al., 2013; Sotomayor-Zarate et al., 2013; Kaminski and Weerts, 2014). The drug was developed as a potent high-affinity partial agonist at $\alpha 4 \beta 2 *$ nAChRs (Reus et al., 2007), but also targets other $n A C h R$ subtypes as well. Therefore, the role of specific nAChR subtypes needs further investigation. Additional $\mathrm{nAChR}$ ligands such as cytisine, a partial agonist at $\alpha 4 \beta 2 *$ and lobeline, a non-selective antagonist were found to reduce alcohol consumption and nicotine-induced alcohol drinking (Bell et al., 2009; Hendrickson et al., 2009; Chatterjee et al., 2011; Sajja and Rahman, 2011, 2012, 2013a).

These nAChR ligands also altered alcohol-induced increases in mesolimbic tissue DA levels (Sajja et al., 2010) in mice, confirming the important role of nAChRs in alcohol drinking and suggesting their involvement in alcohol dependence. Moreover, cytisine and lobeline were found to decrease alcohol self-administration in high alcohol drinking rats (Bell et al., 2009), a genetic animal model for alcohol abuse and dependence (Bell et al., 2012), and mice (Sajja and Rahman, 2011), suggesting that lobeline and cytisine are strong candidates for treating alcohol dependence. Sazetidine-A, a novel compound that selec-

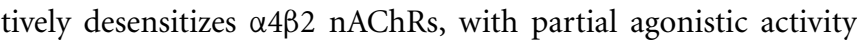
(Xiao et al., 2006; Rezvani et al., 2013), was shown to reduce alcohol drinking in alcohol-preferring rats (Xiao et al., 2006; Rezvani et al., 2010). The evidence suggests that the desensitizing effects of sazetidine on $\alpha 4 \beta 2 \mathrm{nAChR}$ subtypes may account for these reductions in alcohol self-administration. Overall, sazetidine-A may have potential for the management of alcohol dependence by targeting brain nAChR-associated mechansims.

The existing animal and human studies suggest that alcoholinduced activation of the mesolimbic DA system involves brain nAChR stimulation. The rewarding effects of alcohol are dependent on the activation of the nAChRs in the mesolimbic 
DA system (Rollema et al., 2007). Overall, it is clear that brain nAChRs have emerged as critical targets for the reinforcing actions and DA activating effects of alcohol. Thus, ligands or compounds targeting nAChRs, other than those selective for $\alpha 4 \beta 2 \mathrm{nAChRs}$ have potential for treating alcohol dependence in humans. For example, CP-601932 and PF-4575180, partial agonists at $\alpha 3 \beta 4^{*} \mathrm{nAChR}$ were found to reduce alcohol consumption and preference in rats, confirming a role for additional $\mathrm{nAChR}$ subtypes in alcohol dependence (Chatterjee et al., 2011). Overall, nAChR partial agonists, antagonists or other ligands (see Table 2) target several nAChRs, such as $\alpha 4 \beta 2^{*}$ and/or $\alpha 3 \beta 4^{*}$ in order to modulate alcohol self-administration, underscoring the need to conduct more subunit-specific $\mathrm{nAChR}$ research regarding alcohol abuse and dependence. While $\mathrm{nAChR}$ ligands or partial agonists show great promise in reducing alcohol self-administration, evidence indicates that these ligands also decrease the alcohol deprivation effect, a validated animal model of relapse behavior (McKinzie et al., 1998; Spanagel and Hölter, 1999; Rodd et al., 2004; Melendez et al., 2006; Sparta et al., 2009; Bell et al., 2012). Emerging preclinical studies suggest that nicotine exposure re-instates alcohol seeking behaviors in rodents following extinction of alcohol reinforcement (Lê et al., 2003; Hauser et al., 2012). Furthermore, nAChRs were found to regulate deprivationinduced re-exposure of alcohol seeking in long-term alcohol exposed animals (Kuzmin et al., 2009; Rezvani et al., 2010). The nAChR partial agonist varenicline or cytisine that targets $\alpha 4 \beta 2 *$ were found to reduce cue-induced alcohol relapse (Wouda et al., 2011) and the ADE (Sajja and Rahman, 2013a) in animal models. Thus, neurobiological mechanisms associated with relapse are important for new drug developments for alcohol abuse and dependence (McBride et al., 2002; Weiss and Porrino, 2002; Koob and Volkow, 2010).

\section{NICOTINIC RECEPTORS: TARGETS TO TREAT NICOTINE OR OTHER DRUG DEPENDENCE}

Evidence utilizing a wide variety of pharmacological and molecular approaches indicates the important role of nAChRs in modulating nicotine self-administration and associated neurochemical effects (Corrigall et al., 1992; Tuesta et al., 2011). As with alcohol abuse and its treatment, nicotinic ligands that target $\alpha 4 \beta 2 *$ subtypes, particularly those expressed in the mesolimbic DA system, show promise for the management of nicotine addiction (Damaj et al., 1997; Coe et al., 2005; Rollema et al., 2007, 2010; Benowitz, 2009). Several therapeutic drug candidates which are either partial agonists or antagonists at nAChRs have been investigated for nicotine taking behavior in preclinical and clinical studies. Varenicline, an FDA approved medication for smoking cessation and an analog of cytisine, is a partial agonist at $\alpha 4 \beta 2$-containing $\mathrm{nAChRs}$ with higher affinity for this subtype compared to other nAChRs (Coe et al., 2005; Mihalak et al., 2006). Cytisine, a plant alkaloid and a partial agonist at $\alpha 4 \beta 2$ nAChRs (Tutka and Zatoñski, 2006), has been tested in various preclinical models associated with nicotine addiction and is approved for smoking cessation in Europe. Sazetidine-A, a novel $\mathrm{nAChR}$ desensitizing agent and partial agonist with high selectivity for $\alpha 4 \beta 2$ receptors, has been shown to reduce nicotine self-administration in preclinical models (Levin et al., 2010;
Table 2 | Brain nAChR subtypes and pharmacological agents involved in alcohol/nicotine or substance use disorder.

\begin{tabular}{|c|c|c|}
\hline $\begin{array}{l}\text { nAChR subtype/addiction } \\
\text { disorder }\end{array}$ & nAChR ligand & $\begin{array}{l}\text { Primary mode } \\
\text { of action }\end{array}$ \\
\hline
\end{tabular}

$\alpha 4 \beta 2 *$

Cytisine

Partial agonist

AUD or NUDa

$\alpha 4 \beta 2 *$

AUD, NUD, or SUD ${ }^{b}$

$\alpha 4 \beta 2 *$ AUD, or NUDc

Varenicline Partial agonist

Sazetidine A

Desensitizer/

$\alpha 3 \beta 4^{*}$

CP-601932 partial agonist

$\mathrm{AUD}^{\mathrm{d}}$

$\alpha 3 \beta 4^{*}$

$\mathrm{AUD}^{\mathrm{e}}$

$\alpha 4 \beta 2 *$ or other $\beta 2$ containing subtypes

AUD, NUD, or SUD ${ }^{f}$

$\alpha 4 \beta 2 *$ or other $\beta 2$ containing Lobeline Partial agonist

subtypes

AUD or SUDg

$\alpha 3 \beta 4$ *

NUD $^{h}$

$\alpha 4 \beta 2^{*}$

NUDi

$\alpha 6 \beta 2 *$

NUDj

PF-4575180 Partial agonist

Mecamylamine

Antagonist

*Indicates other $\alpha$ or $\beta$ subunits such as $\alpha 3, \alpha 5$, or $\alpha 6$ and $\beta 3$ or $\beta 4$.

AUD, Alcohol use disorder; NUD, Nicotine use disorder; SUD, Substance use disorder

a Bell et al., 2009; Hendrickson et al., 2009; Chatterjee et al., 2011; Sajja and Rahman, 2011, 2012, 2013a.

bSteensland et al., 2007; McKee et al., 2009; Guillem and Peoples, 2010; Hendrickson et al., 2010; Kamens et al., 2010; Bito-Onon et al., 2011; Chatterjee et al., 2011; Wouda et al., 2011; Mitchell et al., 2012; Plebani et al., 2012; Volkow and Skolnick, 2012; Liu et al., 2013; Litten et al., 2013; McKee et al., 2013; Sajja and Rahman, 2013a; Sotomayor-Zarate et al., 2013; Kaminski and Weerts, 2014. cXiao et al., 2006; Levin et al., 2010; Rezvani et al., 2010.

${ }^{d}$ Chatterjee et al., 2011.

e Chatterjee et al., 2011.

${ }^{f}$ Ericson et al., 1998, 2009; Lê et al., 2000; Soderpalm et al., 2000; Blomqvist et al., 2002; Young et al., 2005; Liu et al., 2007; Steensland et al., 2007.

g Bell et al., 2009; Hendrickson et al., 2009; Chatterjee et al., 2011; Sajja and Rahman, 2011, 2012, 2013a,b; Roni and Rahman, 2014.

hToll et al., 2012

iTobey et al., 2012.

j Crooks et al., 2014.

Rezvani et al., 2010). Bupropion, an FDA approved smoking cessation agent was believed to target $\alpha 3 \beta 2$ and/or $\alpha 4 \beta 2 \mathrm{nAChR}$ subtypes in addition to its primary inhibitory mechanisms on the dopamine and norepinephrine transporters (see Crooks et al., 2014). Mecamylamine, a non-selective antagonist at nAChRs, has been investigated and appears to have some efficacy for smoking cessation in a number of clinical studies (Lundahl et al., 2000; Schnoll and Lerman, 2006). Mecamylamine was also reported to decrease cue-induced reinstatement of nicotine-taking behavior (Liu et al., 2007) likely by targeting $\beta 2$-containing nAChR 
subtypes. Nevertheless, the clinical efficacy of mecamylamine is tempered by its peripheral side effects (Rose, 2009). Recently, lobeline, a non-selective antagonist at nAChRs, was found to reduce nicotine withdrawal-induced depression-like behavior; again, likely by targeting $\beta 2-$ containing brain nAChRs (Roni and Rahman, 2014). Thus, lobeline may also have potential in preventing smoking relapse by counteracting nicotine withdrawalinduced depression in humans. Similarly, emerging preclinical studies suggest that selective antagonists at $\alpha$-conotoxin MII $(\alpha-C t x M I I)$ sensitive $\mathrm{nAChR}$ subtypes have great promise in reducing nicotine self-administration (Crooks et al., 2014).

Early work showed that the novel nAChR antagonist N,N'dodecane-1,12-diyl-bis-3-picolinium dibromide reduced nicotine self-administration and nicotine-induced DA function and release in reward-relevant brain regions in preclinical models (Neugebauer et al., 2006; Rahman et al., 2007; Dwoskin et al., 2009), suggesting a possible drug candidate for treating nicotine addiction. Recently, 2-fluro-3-(4-nitrophenyl) deschlroepibatidine, a potent $\alpha 4 \beta 2 \mathrm{nAChR}$ antagonist was found to decrease nicotine self-administration in rats (Tobey et al., 2012). In addition, AT-1001, a high-affinity and selective antagonist at $\alpha 3 \beta 4$ $n A C h R s$ reduced nicotine self-administration in rats (Toll et al., 2012), suggesting an important role for this $\alpha 3 \beta 4$ subtype in nicotine addiction. Taken together, these data indicate that nAChRs, specifically, $\alpha 4 \beta 2^{*} \alpha 3 \beta 2^{*}$ are important therapeutic targets for all three phases of nicotine addiction, including acquisition and maintenance of nicotine- taking behavior, withdrawal symptoms associated with cessation of nicotine-intake and vulnerability to relapse behavior. Thus, emerging partial agonists and/or antagonists (see Table 2) at nAChRs have therapeutic potential that needs to be further investigated and developed for clinical management of nicotine addiction.

Additional drugs such as galantamine, an acetylcholinesterase (AChE) inhibitor and positive allosteric modulator of $\alpha 7$ and $\alpha 4 \beta 2$ nAChRs (Harvey, 1995) has been shown to reduce both nicotine self-administration and reinstatement of nicotineseeking behavior in animal models (Hopkins et al., 2012). Similarly, rivastigmine, another AChE inhibitor attenuates tobacco craving and smoking in alcohol- and methamphetaminedependent smokers (Diehl et al., 2009; De La Garza and Yoon, 2011) and desire to use methamphetamine in the latter (De La Garza et al., 2012). Recently, varenicline was found to reduce the positive subjective effects of methamphetamine in human volunteers suggesting a treatment option for methamphetamine dependence (Verrico et al., 2014). This highlights the important role of the nAChR system in poly-drug abuse and dependence. Taken together, these preclinical and clinical studies suggest that AChE inhibitors likely affect nicotine taking behavior by targeting $\mathrm{nAChRs}$ and ACh levels along with their modulation of other neurotransmitter systems (Hopkins et al., 2012).

With regard to other psychostimulants, a number of nACR antagonists were found to decrease cocaine self-administration, prevent cue-induced craving for cocaine, and to decrease cocaine effects in a place preference paradigm or reduce cocaine-induced behavioral sensitization (Levin et al., 2000; Zachariou et al., 2001; Champtiaux et al., 2006; Hansen and Mark, 2007) suggesting a direct involvement of $\mathrm{nAChRs}$ in cocaine-taking and -seeking behavior. In addition, recent studies indicate that varenicline reduces cocaine-induced reward in rodents and humans (Guillem and Peoples, 2010; Plebani et al., 2012). In contrast, varenicline was found ineffective in reducing cocaine self-administration in a primate model (Gould et al., 2011), indicating mixed effects across models which may be due to species' differences. Consistent with behavioral studies, systemic application of $\mathrm{nAChR}$ antagonists significantly reduces cocaine-induced increases in mesolimbic DA-release (Zanetti et al., 2006). Thus, again, both behavioral and neurochemical evidence support an important role for $\mathrm{nAChRs}$ in cocaine-taking and -seeking behavior. Similar to its effects on cocaine, nAChRs appear to mediate cannabinoid addiction as well. For example, methyllycaconitine, a $\alpha 7^{*} \mathrm{nAChR}$ antagonist was found to reduce 9tetrahydrocannabinol or cannabinoid-1 receptor agonist-induced behavioral and neurochemical effects in animal models, suggesting a critical role in regulating the rewarding effects of cannabinoids (Solinas et al., 2007). Similarly, other animal studies suggest that $\mathrm{nAChRs}$ are also important therapeutic targets for treating opiate addiction (Glick et al., 2002; Biala and Staniak, 2010; Hart et al., 2010; Feng et al., 2011). Overall, emerging data indicates that nAChRs are important targets for psychostimulant abuse and addiction, which will probably involve targeting specific nAChR subtypes and their neuromodulatory mechanisms.

\section{NICOTINIC RECEPTOR GENE VARIATIONS AND ADDICTION}

Finally, given the increasingly recognized role of pharmacogenetics/pharmacogenomics in the treatment of addiction (e.g., King et al., 2012; Uhl et al., 2014), it is important to provide a general statement on some of the polymorphisms with a significant association to the initiation, maintenance, relapse, craving and/or treatment outcomes related to addiction. Given the primary addictive component of ingested tobacco is nicotine, it stands to reason that by far the addictive behavior most commonly examined, regarding its association with the $\mathrm{nAChR}$, is nicotine/tobacco addiction. In Indian subjects, variations in the CHRNA5 risk polymorphism (rs16969968) are associated with increased probability of nicotine dependence (Anantharaman et al., 2014). The CHRNA5 risk polymorphism (rs16969968) also has a significant association with nicotine addiction strength (level of physical addiction) with different allelic expression conferring either increased or decreased levels of nicotine dependence (Wojas-Krawczyk et al., 2012). In addition, the CHRNA5 risk polymorphism (rs16969968) is associated with significant increases in $\mathrm{PMRI}$ activity of women shown smoking images (Janes et al., 2012). Similarly, in female Canadian citizens of Ontario, the presence of the CHRNA5 risk polymorphism (rs16969968) significantly increased the probability of heavy smoking, whereas the presence of the CHRNA3 polymorphism (rs578775) significantly decreased the probability of heavy smoking (Conlon and Bewick, 2011).

Other work has shown that the normal nicotine metabolizing CYP2A6 genotype can increase the positive association of the CHRNA3 risk polymorphism (rs1051730) with nicotine dependence (Wassenaar et al., 2011). The CHRNA3 risk polymorphism (rs1051730) has been shown to have a significant association with level of nicotine in two heavy smoking regional Italian 
populations (Sorice et al., 2011). The CHRNA3 risk polymorphism (rs1051730) also has a significant association with shortterm (4 week) nicotine abstinence-rates in treatment-seeking smokers (Munafo et al., 2011); although, another study did not find a significant association between this polymorphism and willingness to quit smoking (Marques-Vidal et al., 2011). Two other polymorphisms that have significant predictive value for smoking cessation following treatment with a transdermal nicotine patch and/or bupropion are the CHRNA5 (rs680244) and CHRNB4 (rs12914008) polymorphisms (Sarginson et al., 2011). In an early Finnish study, it was found that variations in the CHRNG-CHRND gene cluster on chromosome 2 were significantly associated with cotinine levels but not number of cigarettes smoked per day suggesting a possible gene-gene interaction with nicotine metabolizing genes (Keskitalo-Vuokko et al., 2011).

Variants in the CHRNA2 and CHRNA6 on chromosome 8 are also associated with increased risk for nicotine dependence in Americans, with the latter being significant in both those of European and African descent and the former being significant in only those of African descent (Wang et al., 2014). A previous study found that the CHRNB3 risk polymorphism (rs1451240) significantly increased the probability of having nicotine dependence in Americans of both European and African descent (Rice et al., 2012). A parallel study found that missense variants in CHRNB4 actually decreased the risk for nicotine dependence in Americans of both European and African descent (Haller et al., 2012). Moreover, these authors reported that an in vitro analysis revealed that the minor (protective) allele was associated with increased cellular response to nicotine. In male Japanese subjects, the CHRNB2 polymorphism (rs4845652) may confer protection against nicotine dependence, whereas a combination of this polymorphism with the CHRNA4 risk polymorphism (rs1044397) leads to higher nicotine dependence scores (Chen et al., 2013).

Similar to the study in Japan (Chen et al., 2013), an early study with male Chinese smokers revealed that the CHRNA4 risk polymorphism (rs1044396) was significantly associated with age at smoking initiation and the CHRNA4 risk polymorphisms (rs1044396 and rs1044397) were associated with nicotine dependence (Chu et al., 2011). In subjects from the Center on Antisocial Drug Dependence (CADD), the minor alleles of CHRNA4 risk polymorphisms (rs1044396 and rs1044394) are associated with a significantly greater propensity to develop nicotine dependence than otherwise (Kamens et al., 2013). In Alaska Natives, the nicotine dependence risk polymorphism (rs578776) in the $30 \mathrm{~kb}$ CHRNA5-A3-B4 region was significantly associated with level of nicotine intake (Zhu et al., 2013). In European treatment-seeking smokers, the CHRNA4 risk polymorphism (rs3787138) is associated with an increased risk for both nicotine withdrawal and depression (Lazary et al., 2014).

Evaluation of nicotinic receptor gene variations and other addictions include the observation that, in a case-control study on internet addiction in Germany, the CHRNA4 polymorphism rs1044396 occurred significantly more often in those presenting with internet addiction than their controls (Montag et al., 2012). Using a nationally representative sample, significant associations between CHRNA6 polymorphisms (rs1072003, rs2304297, and rs892413) as well as CHRNB3 polymorphism (rs13280604) and excessive alcohol-drinking behavior have been reported (Hoft et al., 2009). In other work, a study from the Nicotine Addiction Genetics consortium in Finland reported a significant association between the CHRNB4 polymorphism rs11636753 and regular alcohol drinking with comorbidity for depression (Broms et al., 2012). Moreover, these authors reported that the effect appeared to be driven primarily by the females in the sample suggesting a sex-dependent effect. In earlier studies than those discussed above it was reported that the CHRNA5 risk polymorphism (rs16969968) is not only associated with nicotine dependence but it is also associated with opioid (Erlich et al., 2010) and cocaine (Sherva et al., 2010) dependence as well. Other CHRNA5 polymorphisms (rs615470 and rs684513) have significant associations with alcohol and cocaine dependence, respectively (Sherva et al., 2010). Another study examining polymorphisms within the CHRNA5-A3-B4 gene cluster found a significant association with the age at initiating drug use across multiple types of drugs of abuse (Lubke et al., 2012). Combined, these findings indicate that multiple polymorphisms associated with nAChR gene have been identified that predict dependence to a number of abuse substances or associated behaviors across national, ethnic and psychiatric groups. The fact that these results span several populations supports the reliability of these findings.

\section{SUMMARY AND CONCLUSIONS}

Due to the limited efficacy of existing FDA approved medications as indicated by continued significant relapse rates, there is a great impetus for determining alternative neuronal brain targets and strategies in the treatment of addiction. As outlined above, significant progress has been made in determining the role that the nicotinic cholinergic system plays in alcohol and drug dependence through both preclinical and clinical studies. Therefore, modulation of brain nAChRs represents a potential therapeutic strategy for treating alcohol and drug dependence. In general, the variety of $n A C h R$ subtypes, the respective stoichiometry profile of their respective subunits, their specific localization within the brain, and downstream effects from $\mathrm{nAChR}$ activation have been shown to mediate, at least in part, the complex behavioral and neurobiological effects of alcohol and drugs of abuse. Recent studies support the clinical management of alcohol dependence with varenicline and other $\mathrm{nAChR}$ partial agonists and/or antagonists, such as mecamylamine, especially among heavy smokers. Further, both chronic alcohol drinking and chronic nicotine exposure affect neural circuits (e.g., hippocampus and prefrontal cortex) mediating cognitive activities such as attention and decisionmaking. Hence, the use of nAChR-based ligands could improve impaired cognitive function associated with chronic alcohol or nicotine exposure facilitating cognitive and behavioral treatments targeting addiction. Regarding reward and reinforcement, chronic alcohol and drug use enhances cholinergic activity within the mesocorticolimbic dopamine system (e.g., ventral tegmental area) that causes desensitization of nAChR-mediated activity. Therefore, the level and role of neuroplastic changes within this reward system requires further investigation. While the development of nAChR subtype-specific ligands holds great potential for future pharmacotherapies targeting alcohol and drug dependence, possible adverse side-effects associated with these ligands 
reiterates the need to study these effects before committing them to clinical use. Nevertheless, the substantial health burden that alcohol and drug addiction place on society mandates the recognition that clinical efficacy may outweigh the possible side-effects of a particular nicotinergic system modulator.

In addition, while a global role for the cholinergic system in addiction has been established, the unique role for specific $\mathrm{nAChR}$ subtypes has yet to be determined. As these issues are studied, the field will have a better understanding of the neurocircuitry as well as cellular and molecular processes involved in alcohol and drug dependence. With this knowledge, we will be able to develop small molecules that can disrupt, and possibly reverse, the addictive process associated with the cholinergic system's, as well as its control of other neuromodulatory systems, mediation of alcohol and drug dependence. Despite some mixed results, or limited outcomes, of clinical or human laboratory trials using some of these nAChR ligands, there remains considerable potential for additional translational research on the cholinergic system in developing therapeutic management strategies for alcohol and drug dependence. The breadth of these findings in combination with a substantial literature on Genome Wide Association Studies, argue persuasively that future drug development will include small molecules targeting central cholinergic activity resulting in more effective treatments for alcohol, nicotine and other drug addictions.

\section{ACKNOWLEDGMENTS}

Preparation of this manuscript was supported in part by the grants from Juhnke Endowment Fund and South Dakota State University Foundation (Shafiqur Rahman); AA13522 (Richard L. Bell), and AA020396 (Eric A. Engleman, Richard L. Bell) from the National Institutes of Health (NIH)/National Institute on Alcohol Abuse and Alcoholism (NIAAA). The views expressed herein are solely those of the authors and do not necessarily reflect the views of the funding organizations, NIH or NIAAA.

\section{REFERENCES}

Albuquerque, E. X., Pereira, E. F. R., Alkondon, M., and Rogers, S. W. (2009). Mammalian nicotinic acetylcholine receptors: from structure to function. Physiol. Rev. 89, 73-120. doi: 10.1152/physrev.00015.2008

Alkondon, M., Pereira, E. F., Barbosa, C. T., and Albuquerque, E. X. (1997). Neuronal nicotinic Acetylcholine receptor activation modulates $\gamma$ aminobutyric acid release from CAl neurons of rat hippocampal slices. J. Pharmacol. Exp. Ther. 283, 1396-1411.

Anantharaman, D., Chabrier, A., Gaborieau, V., Franceschi, S., Herrero, R., Rajkumar, T., et al. (2014). Genetic variants in nicotine addiction and alcohol metabolism genes, oral cancer risk and the propensity to smoke and drink alcohol: a replication study in India. PLOS ONE 9:e88240. doi: 10.1371/journal.pone. 0088240

Bell, R. L., Eiler, B. J., Cook, J. B., and Rahman, S. (2009). Nicotinic receptor ligands reduce ethanol intake by high alcohol-drinking HAD-2 rats. Alcohol 43, 581-592. doi: 10.1016/j.alcohol.2009.09.027

Bell, R. L., Sable, H. J. K., Colombo, G., Hyytia, P., Rodd, Z. A., and Lumeng, L. (2012). Animal models for medications development targeting alcohol abuse using selectively bred rat lines: neurobiological and pharmacological validity. Pharmacol. Biochem. Behav. 103, 119-155. doi: 10.1016/j.pbb.2012.07.007

Benowitz, N. L. (2009). Pharmacology of nicotine: addiction, smoking-induced disease, and therapeutics. Annu. Rev. Pharmacol. Toxicol. 49, 57-71. doi: 10.1146/annurev.pharmtox.48

Biala, G., and Staniak, N. (2010). Varenicline and mecamylamine attenuate locomotor sensitization and cross-sensitization induced by nicotine and morphine in mice. Pharmacol. Biochem. Behav. 96, 141-147. doi: 10.1016/j.pbb.2010.04.022

Bito-Onon, J. J., Simms, J. A., Chatterjee, S., Holgate, J., and Bartlett, S. E. (2011). Varenicline, a partial agonist at neuronal nicotinic acetylcholine receptors, reduces nicotine-induced increases in $20 \%$ ethanol operant self-administration in Sprague-Dawley rats. Addict. Biol. 16, 440-449. doi: 10.1111/j.13691600.2010.00309.x

Blomqvist, O., Engel, J. A., Nissbrandt, H., and Söderpalm, B. (1993). The mesolimbic dopamine-activating properties of ethanol are antagonized by mecamylamine. Eur. J. Pharmacol. 249, 207-213. doi: 10.1016/0014-2999(93)90434-J

Blomqvist, O., Ericson, M., Johnson, D. H., Engel, J. A., and Söderpalm, B. (1996). Voluntary ethanol intake in the rat: effects of nicotinic acetylcholine receptor blockade or subchronic nicotine treatment. Eur. J. Pharmacol. 314, 257-267. doi: 10.1016/S0014-2999(96)00583-3

Blomqvist, O., Hernandez-Avila, C. A., Van Kirk, J., Rose, J. E., and Kranzler, H. R. (2002). Mecamylamine modifies the pharmacokinetics and reinforcing effects of alcohol. Alcohol. Clin. Exp. Res. 26, 326-331. doi: 10.1111/j.15300277.2002.tb02541.x

Broms, U., Wedenoja, J., Largeau, M. R., Korhonen, T., Pitkaniemi, J., KeskitaloVuokko, K., et al. (2012). Analysis of detailed phenotype profiles reveals CHRNA5-CHRNA3-CHRNB4 gene cluster association with several nicotine dependence traits. Nic. Tob. Res. 14, 720-733. doi: 10.1093/ntr/ntr283

Buccafusco, J. J., Beach, W., and Terry, A. V. (2009). Desensitization of nicotinic acetylcholine receptors as a strategy for drug development. J. Pharmacol. Exp. Ther. 328, 364-370. doi: 10.1124/jpet.108.145292

Champtiaux, N., Gotti, C., Cordero-Erausquin, M., David, D. J., Przybylski, C., Léna, C., et al. (2003). Subunit composition of functional nicotinic receptors in dopaminergic neurons investigated with knock-out mice. J. Neurosci. 23, 7820-7829. Available online at: http://www.jneurosci.org/content/23/21/7820. long

Champtiaux, N., Han, Z. Y., Bessis, A., Rossi, F. M., Zoli, M., Marubio, L., et al. (2002). Distribution and pharmacology of alpha 6-containing nicotinic acetylcholine receptors analyzed with mutant mice. J. Neurosci. 22, 1208-1217. Available online at: http://www.jneurosci.org/content/22/4/1208.long

Champtiaux, N., Kalivas, P. W., and Bardo, M. T. (2006). Contribution of dihydrobeta-erythroidine sensitive nicotinic acetylcholine receptors in the ventral tegmental area to cocaine-induced behavioral sensitization in rats. Behav. Brain Res. 168, 120-126. doi: 10.1016/j.bbr.2005.10.017

Changeux, J. P. (2010). Nicotine addiction and nicotinic receptors: lessons from genetically modified mice. Nat. Rev. Neurosci. 11, 389-401. doi: 10.1038/nrn2849

Chatterjee, S., and Bartlett, S. E. (2010). Neuronal nicotinic acetylcholine receptors as pharmacotherapeutic targets for the treatment of alcohol use disorders. CNS Neurol. Dis. Drug Targets 9, 60-76. doi: 10.2174/187152710790966597

Chatterjee, S., Steensland, P., Simms, J. A., Holgate, J., Hurst, R. S., Shaffer, C. L., et al. (2011). Partial agonists of the alpha3beta4 neuronal nicotinic acetylcholine receptor reduce ethanol consumption and seeking in rats. Neuropsychopharmacology 36, 603-615. doi: 10.1038/npp.2010.191

Chen, H. I., Shinkai, T., Utsunomiya, K., Yamada, K., Sakata, S., Fukunaka, Y., et al. (2013). Possible association of nicotinic acetylcholine receptor gene (CHRNA4 and CHRNB2) polymorphisms with nicotine dependence in Japanese males: an exploratory study. Pharmacopsychiatry 46, 77-82. doi: 10.1055/s-0032-1323678

Chi, H., and de Wit, H. (2003). Mecamylamine attenuates the subjective stimulantlike effects of alcohol in social drinkers. Alcohol. Clin. Exp. Res. 27, 780-786. doi: 10.1097/01.ALC.0000065435.12068.24

Chu, C. J., Yang, Y. C., Wei, J. X., and Zhang, L. (2011). Associations of nicotinic acetylcholine receptor subunit alpha-4 polymorphisms with smoking behaviors in Chinese male smokers. Chin. Med. J. 124, 1634-1638.

Clark, L., and Robbins, T. (2002). Decision-making deficits in drug addiction. Trends Cogn. Sci. 6, 361. doi: 10.1016/S1364-6613(02)01960-5

Clarke, P., and Reuben, M. (1996). Release of $\left[{ }^{3} \mathrm{H}\right]$-noradrenaline from rat hippocampal Synaptosomes by nicotine: mediation by different nicotinic receptor subtypes from striatal $\left[{ }^{3} \mathrm{H}\right]$-dopamine release. Br. J. Pharmacol. 117, 595-606. doi: 10.1111/j.1476-5381.1996.tb15232.x

Coe, J. W., Brooks, P. R., Vetelino, M. G., Wirtz, M. C., Arnold, E. P., Huang, J., et al. (2005). Varenicline: an alpha4beta2 nicotinic receptor partial agonist for smoking cessation. J. Med. Chem. 48, 3474-3477. doi: 10.1021/jm050069n

Conlon, M. S., and Bewick, M. A. (2011). Single nucleotide polymorphisms in CHRNA5 rs16969968, CHRNA3 rs578776, and LOC123688 rs8034191 are 
associated with heaviness of smoking in women in northeastern Ontario, Canada. Nic. Tob. Res. 13, 1076-1083. doi: 10.1093/ntr/ntr140

Corrigall, W. A., Franklin, K. B. J., Coen, K. M., and Clarke, P. B. S. (1992). The mesolimbic dopamine system is implicated in the reinforcing effects of nicotine. Psychopharmacology 107, 285-289. doi: 10.1007/BF02245149

Crooks, P. A., Bardo, M. T., and Dwoskin, L. P. (2014). Nicotinic receptor antagonists as treatments for nicotine abuse. Adv. Pharmacol. 69, 513-551. doi: 10.1016/B978-0-12-420118-7.00013-5

Damaj, M. I., Patrick, G. S., Creasy, K. R., and Martin, B. R. (1997). Pharmacology of lobeline, a nicotinic receptor ligand. J. Pharmacol. Exp. Ther. 282, 410-419.

Dani, J. A., and Bertrand, D. (2007). Nicotinic acetylcholine receptors and nicotinic cholinergic mechanisms of the central nervous system. Annu. Rev. Pharmacol. Toxicol. 47, 699-729. doi: 10.1146/annurev.pharmtox.47.120505.105214

Davies, D. L., Bortolato, M., Finn, D. A., Ramaker, M. J., Barak, S., Ron, D., et al. (2013). Recent advances in the discovery and preclinical testing of novel compounds for the prevention and/or treatment of alcohol use disorders. Alcohol. Clin. Exp. Res. 37, 8-15. doi: 10.1111/j.1530-0277.2012.01846.x

De La Garza, R. II, Newton, T. F., Haile, C. N., Yoon, J. H., Nerumalla, C. S., Mahoney, J. J. III, et al. (2012). Rivastigmine reduces "likely to use methamphetamine" in methamphetamine-dependent volunteers. Prog. Neuropsychopharmacol. Biol Psychiatry 37, 141-146. doi: 10.1016/j.pnpbp.2011. 12.014

De La Garza, R., and Yoon, J. H. (2011). Evaluation of the effects of rivastigmine on cigarette smoking by methamphetamine-dependent volunteers. Prog. Neuropsychopharmacol. Biol. Psychiatry 35, 1827-1830. doi: 10.1016/j.pnpbp.2011.07.006

Diehl, A., Nakovics, H., Mutschler, J., Hermann, D., and Kiefer, F. (2009). Rivastigmine reduces tobacco craving in alcohol-dependent smokers. Pharmacopsychiatry 42, 89-94. doi: 10.1055/s-0028-1103295

Dwoskin, L. P., Smith, A. M., Wooters, T. E., Zhang, Z., Crooks, P. A., and Bardo, M. T. (2009). Nicotinic receptor-based therapeutics and candidates for smoking cessation. Biochem. Pharmacol. 78, 732-743. doi: 10.1016/j.bcp.2009. 06.002

Ericson, M., Blomqvist, O., Engel, J. A., and Söderpalm, B. (1998). Voluntary ethanol intake in the rat and the associated accumbal dopamine overflow are blocked by ventral tegmental mecamylamine. Eur. J. Pharmacol. 358, 189-196. doi: 10.1016/S0014-2999(98)00602-5

Ericson, M., Löf, E., Stomberg, R., and Söderpalm, B. (2009). The smoking cessation medication varenicline attenuates alcohol and nicotine interactions in the rat mesolimbic dopamine system. J. Pharmacol. Exp. Ther. 329, 225-230. doi: 10.1124/jpet.108.147058

Erlich, P. M., Hoffman, S. N., Rukstalis, M., Han, J. J., Chu, X., Linda Kao, W. H., et al. (2010). Nicotinic acetylcholine receptor genes on chromosome 15q25.1 are associated with nicotine and opioid dependence severity. Hum. Genet. 128, 491-499. doi: 10.1007/s00439-010-0876-6

Feduccia, A. A., Chatterjee, S., and Bartlett, S. E. (2012). Neuronal nicotinic acetylcholine receptor: neuroplastic changes underlying alcohol and nicotine addictions. Front. Mol. Neurosci. 5:83. doi: 10.3389/fnmol.2012. 00083

Feng, B., Xing, J. H., Jia, D., Liu, S. B., Guo, H. J., Li, X. Q., et al. (2011). Blocking $\alpha 4 \beta 2$ and $\alpha 7$ nicotinic acetylcholine receptors inhibits the reinstatement of morphine-induced CPP by drug priming in mice. Behav. Brain Res. 220, 100-105. doi: 10.1016/j.bbr.2011.01.040

Flores, C. M., Rogers, S. W., Pabreza, L. A., Wolfe, B. B., and Kellar, K. (1992). A subtype of Nicotinic cholinergic receptor in rat brain is composed of alpha 4 and beta 2 subunits and is up- Regulated by chronic nicotine treatment. Mol. Pharmacol. 41, 31-37.

Fowler, C. D., Arends, M. A., and Kenny, P. J. (2008). Subtypes of nicotinic acetylcholine receptors in nicotine reward, dependence, and withdrawal: evidence from genetically modified mice. Behav. Pharmacol. 19, 461-484. doi: 10.1097/FBP.0b013e32830c360e

Gallego, X., Ruiz-Medina, J., Valverde, O., Molas, S., Robles, N., Sabrià, J., et al. (2012). Transgenic over expression of nicotinic receptor alpha 5, alpha 3 , and beta 4 subunit genes reduces ethanol intake in mice. Alcohol 46, 205-215. doi: 10.1016/j.alcohol.2011.11.005

Glick, S. D., Maisonneuve, I. M., Kitchen, B. A., and Fleck, M. W. (2002). Agonism of alpha 3 beta 4 nicotinic receptors as a strategy to reduce opioid and stimulant self-administration. Eur. J. Pharmacol. 438, 99-105. doi: 10.1016/S0014-2999(02)01284-0
Gotti, C., Clementi, F., Fornari, A., Gaimarri, A., Guiducci, S., Manfredi, I., et al. (2009). Structural and functional diversity of native brain nicotinic receptors. Biochem. Pharmacol. 78, 703-711. doi: 10.1016/j.bcp.2009.05.024

Gotti, C., Moretti, M., Gaimarri, A., Zanardi, A., Clementi, F., and Zoli, M. (2007). Heterogeneity and complexity of native brain nicotinic receptors. Biochem. Pharmacol. 74, 1102-1111. doi: 10.1016/j.bcp.2007.05.023

Gould, R. W., Czoty, P. W., Nader, S. H., and Nader, M. A. (2011). Effects of varenicline on the reinforcing and discriminative stimulus effects of cocaine in rhesus monkeys. J. Pharmacol. Exp. Ther. 339, 678-686. doi: 10.1124/jpet.111.185538

Grady, S., Marks, M. J., Wonnacott, S., and Collins, A. C. (1992). Characterization of nicotinic receptor-mediated $\left[{ }^{3} \mathrm{H}\right]$ dopamine release from synaptosomes prepared from mouse striatum. J. Neurochem. 59, 848-856. doi: 10.1111/j.14714159.1992.tb08322.x

Guillem, K., and Peoples, L. L. (2010). Varenicline effects on cocaine self administration and reinstatement behavior. Behav. Pharmacol. 21, 96-103. doi: 10.1097/FBP.0b013e328336e9c5

Haller, G., Druley, T., Vallania, F. L., Mitra, R. D., Li, P., Akk, G., et al. (2012). Rare missense variants in CHRNB4 are associated with reduced risk of nicotine dependence. Hum. Mol. Genet. 21, 647-655. doi: 10.1093/hmg/ddr498

Hansen, S. T., and Mark, G. P. (2007). The nicotinic acetylcholine receptor antagonist mecamylamine prevents escalation of cocaine self-administration in rats with extended daily access. Psychopharmacology 194, 53-61. doi: 10.1007/s00213-007-0822-z

Hart, N., Rocha, A., Miller, D. K., and Nation, J. R. (2010). Dose-dependent attenuation of heroin self-administration with lobeline. J. Psychopharmacol. 24, 51-55. doi: 10.1177/0269881108092119

Harvey, A. L. (1995). The pharmacology of galantamine and its analogues. Pharmacol. Ther. 68, 113-128. doi: 10.1016/0163-7258(95)02002-0

Hauser, S. R., Getachew, B., Oster, S. M., Dhaher, R., Ding, Z.-M., Bell, R. L., et al. (2012). Nicotine modulates alcohol-seeking and relapse by alcohol-preferring (P) rats in a time dependent manner. Alcohol. Clin. Exp. Res. 36, 43-54. doi: 10.1111/j.1530-0277.2011.01579.x

Hendrickson, L. M., Guildford, M. J., and Tapper, A. R. (2013). Neuronal nicotinic acetylcholine receptors: common molecular substrates of nicotine and alcohol dependence. Front. Psychiatry 4:29. doi: 10.3389/fpsyt.2013.00029

Hendrickson, L. M., Zhao-Shea, R., Pang, X., Gardner, P. D., and Tapper, A. R. (2010). Activation of alpha $4^{*} \mathrm{nAChRs}$ is necessary and sufficient for vareniclineinduced reduction of alcohol consumption. J. Neurosci. 30, 10169-10176. doi: 10.1523/JNEUROSCI.2601-10.2010

Hendrickson, L. M., Zhao-Shea, R., and Tapper, A. R. (2009). Modulation of ethanol drinking-in-the-dark by mecamylamine and nicotinic acetylcholine receptor agonists in C57BL/6J mice. Psychopharmacology 204, 563-572. doi: 10.1007/s00213-009-1488-5

Hoft, N. R., Corley, R. P., McQueen, M. B., Huizinga, D., Menard, S., and Ehringer, M. A. (2009). SNPs in CHRNA6 and CHRNB3 are associated with alcohol consumption in a nationally representative sample. Genes Brain Behav. 8, 631-637. doi: 10.1111/j.1601-183X.2009.00495.x

Hogg, R. C., Raggenbass, M., and Bertrand, D. (2003). Nicotinic acetylcholine receptors from structure to brain function. Biochem. Pharmacol. 147, 1-46. doi: 10.1007/s10254-003-0005-1

Hopkins, T. J., Rupprecht, L. E., Hayes, M. R., Blendy, J. A., and Schmidt, H. D. (2012). Galantamine, an acetylcholinesterase inhibitor and positive allosteric modulator of nicotinic acetylcholine receptors attenuates nicotine taking and seeking in rats. Neuropsychopharmacology 37, 2310-2321. doi: 10.1038/npp.2012.83

Hurst, R., Rollema, H., and Bertrand, D. (2013). Nicotinic acetylcholine receptors: from basic science to therapeutics. Pharmacol. Ther. 137, 22-54. doi: 10.1016/j.pharmthera.2012.08.012

Janes, A. C., Smoller, J. W., David, S. P., Frederick, B. D., Haddad, S., Basu, A., et al. (2012). Association between CHRNA5 genetic variation at rs 16969968 and brain reactivity to smoking images in nicotine dependent women. Drug Alcohol Depend. 120, 7-13. doi: 10.1016/j.drugalcdep.2011.06.009

Kamens, H. M., Anderson, J., and Picciotto, M. R. (2010). Modulation of ethanol consumption by genetic and pharmacological manipulation of nicotinic acetylcholine receptors in mice. Psychopharmacology 208, 613-626. doi: 10.1007/s00213-009-1759-1

Kamens, H. M., Corley, R. P., McQueen, M. B., Stallings, M. C., Hopfer, C. J., Crowley, T. J., et al. (2013). Nominal association with CHRNA4 variants and nicotine dependence. Genes Brain Behav. 12, 297-304. doi: 10.1111/gbb.12021 
Kaminski, B. J., and Weerts, E. M. (2014). The effects of varenicline on alcohol seeking and self-administration in baboons. Alcohol. Clin. Exp. Res. 38, 376-383. doi: 10.1111/acer.12233

Keskitalo-Vuokko, K., Pitkaniemi, J., Broms, U., Heliovaara, M., Aromaa, A., Perola, M., et al. (2011). Associations of nicotine intake measures with CHRN genes in Finnish smokers. Nic. Tob. Res. 13, 686-690. doi: 10.1093/ntr/ntr059

King, D. P., Paciga, S., Pickering, E., Benowitz, N. L., Bierut, L. J., Conti, D. V., et al. (2012). Neuropsychopharmacology 37, 641-650. doi: 10.1038/npp.2011.232

Klink, R., de Kerchove d'Exaerde, A., Zoli, M., and Changeux, J. P. (2001). Molecular and physiological diversity of nicotinic acetylcholine receptors in the midbrain dopaminergic nuclei. J. Neurosci. 21, 1452-1463.

Koob, G. F., and Volkow, N. D. (2010). Neurocircuitry of addiction. Neuropsychopharmacology 35, 217-238. doi: 10.1038/npp.2009.110

Kuzmin, A., Jerlhag, E., Liljequist, S., and Engel, J. A. (2009). Effects of subunit selective $\mathrm{nAChR}$ receptors on operant ethanol self-administration and relapse-like ethanol-drinking behavior. Psychopharmacology 203, 99-108. doi: 10.1007/s00213-008-1375-5

Larsson, A., and Engel, J. A. (2004). Neurochemical and behavioral studies on ethanol and nicotine interactions. Neurosci. Biobehav. Rev. 27, 713-720. doi: 10.1016/j.neubiorev.2003.11.010

Larsson, A., Svensson, L., Söderpalm, B., and Engel, J. A. (2002). Role of different nicotinic Acetylcholine receptors in mediating behavioral and neurochemical effects of ethanol in mice. Alcohol 28, 157-167. doi: 10.1016/S07418329(02)00244-6

Lazary, J., Dome, P., Csala, I., Kovacs, G., Faludi, G., Kaunisto, M., et al. (2014). Massive withdrawal symptoms and affective vulnerability are associated with variants of the CHRNA4 gene in a subgroup of smokers. PLoS ONE 9:e87141. doi: 10.1371/journal.pone.0087141

Lê, A. D., Corrigall, W. A., Harding, J. W., Juzytsch, W., and Li, T.-K. (2000). Involvement of nicotinic receptors in alcohol self-administration. Alcohol. Clin. Exp. Res. 24, 155-163. doi: 10.1111/j.1530-0277.2000.tb04585.x,

Lê, A. D., Li, Z., Funk, D., Shram, M., Li, T.-K., and Shaham, Y. (2003). Nicotine increases alcohol self-administration and reinstates alcohol seeking in rats. Psychopharmacology 168, 216-221. doi: 10.1007/s00213-002-1330-9

Leibson, T., Neuman, G., Chudley, A. E., and Koren, G. (2014). The differential diagnosis of fetal alcohol spectrum disorder. J. Popul. Ther. Clin. Pharmacol. 21, e1-e30.

Le Novere, N., Zoli, M., and Changeux, J. P. (1996). Neuronal nicotinic receptor alpha 6 subunit mRNA is selectively concentrated in catecholaminergic nuclei of the rat brain. Eur. J. Neurosci. 8, 2428-2439. doi: 10.1111/j.14609568.1996.tb01206.x,

Levin, E. D., Mead, T., Rezvani, A. H., Rose, J. E., Gallivan, C., and Gross, R. (2000). The nicotinic antagonist mecamylamine preferentially inhibits cocaine vs. food self-administration in rats. Physiol. Behav. 71, 565-570. doi: 10.1016/S00319384(00)00382-6

Levin, E. D., Rezvani, A. H., Xiao, Y., Slade, S., Cauley, M., Wells, C., et al. (2010). Sazetidine-A, a selective alpha4beta2 nicotinic receptor desensitizing agent and partial agonist, reduces nicotine self-administration in rats. J. Pharmacol. Exp. Ther. 332, 933-939. doi: 10.1124/jpet.109.162073

Litten, R. Z., Egli, M., Heilig, M., Cui, C., Fertig, J. B., Ryan, M. L., et al. (2012). Medications development to treat alcohol dependence: a vision for the next decade. Addict. Biol. 17, 513-527. doi: 10.1111/j.1369-1600.2012.00454.x

Litten, R. Z., Ryan, M. L., Fertig, J. B., Falk, D. E., Johnson, B., Dunn, K. E., et al. (2013). A double-blind, placebo-controlled trial assessing the fficacy of varenicline tartrate for alcohol dependence. J. Addict. Med. 7, 277-286. doi: 10.1097/ADM.0b013e31829623f4

Liu, L., Hendrickson, L. M., Guildford, M. J., Zhao-Shea, R., Gardner, P. D., and Tapper, A. R. (2013). Nicotinic acetylcholine receptors containing the $\alpha 4$ subunit modulate alcohol reward. Biol. Psychiatry 73, 738-746. doi: 10.1016/j.biopsych.2012.09.019

Liu, X., Caggiula, A. R., Yee, S. K., Nobuta, H., Sved, A. F., Pechnick, R. N., et al. (2007). Mecamylamine attenuates cue-induced reinstatement of nicotine-seeking behavior in rats. Neuropsychopharmacology 32, 710-718. doi: 10.1038/sj.npp.1301129

Livingstone, P. D., and Wonnacott, S. (2009). Nicotinic acetylcholine receptors and the ascending dopamine pathways. Biochem. Pharmacol. 78, 744-755. doi: 10.1016/j.bcp.2009.06.004

Lubke, G. H., Stephens, S. H., Lessem, J. M., Hewitt, J. K., and Ehringer, M. A. (2012). The CHRNA5/A3/B4 gene cluster and tobacco, alcohol, cannabis, inhalants and other substance initiation: replication and new findings using mixture analyses. Behav. Genet. 42, 636-646. doi: 10.1007/s10519-012-9529-y

Lundahl, L. H., Henningfield, J. E., and Lukas, S. E. (2000). Mecamylamine blockade of both positive and negative effects of IV nicotine in human volunteers. Pharmacol. Biochem. Behav. 66, 637-643. doi: 10.1016/S0091-3057(00)00252-5

Luo, S., Kulak, J. M., Cartier, G. E., Jacobsen, R. B., Yoshikami, D., Olivera, B. M., et al. (1998). $\alpha$-Conotoxin AuIB selectively blocks $\alpha 3 \beta 4$ nicotinic acetylcholine receptors and nicotine-evoked norepinephrine release. J. Neurosci. 18, 8571-8579.

Mansvelder, H. D., Keath, J. R., and McGehee, D. S. (2002). Synaptic mechanisms underlie nicotine- Induced excitability of brain reward areas. Neuron 33, 905-919. doi: 10.1016/S0896-6273(02)00625-6

Marques-Vidal, P., Kutalik, Z., Paccaud, F., Bergman, S., Waeber, G., Vollenweider, P., et al. (2011). Variant within the promotor region of the CHRNA3 gene associated with FTN dependence is not related to self-reported willingness to quit smoking. Nic. Tob. Res. 13, 833-839. doi: 10.1093/ntr/ntr084

McBride, W. J., Le, A. D., and Noronha, A. (2002). Central nervous system mechanisms in alcohol relapse. Alcohol. Clin. Exp. Res. 26, 280-286. doi: 10.1111/j.1530-0277.2002.tb02535.x

McKee, S. A., Harrison, E. L., O’Malley, S. S., Krishnan-Sarin, S., Shi, J., Tetrault, J. M., et al. (2009). Varenicline reduces alcohol selfadministration in heavy-drinking smokers. Biol. Psychiatry 66, 185-190. doi: 10.1016/j.biopsych.2009.01.029

McKee, S. A., Young-Wolff, K. C., Harrison, E. L., Cummings, K. M., Borland, R., Kahler, C. W., et al. (2013). Longitudinal associations between smoking cessation medications and alcohol consumption among smokers in the International Tobacco Control Four Country Survey. Alcohol. Clin. Exp. Res. 37, 804-810. doi: 10.1111/acer.12041

McKinzie, D. L., Nowak, K. L., Yorger, L., McBride, W. J., Murphy, J. M., Lumeng, L., et al. (1998). The alcohol deprivation effect in the alcohol preferring P rat under free-drinking and operant conditions. Alcohol. Clin. Exp. Res. 22, 1170-1176. doi: 10.1111/j.1530-0277.1998.tb03718.x

Melendez, R. I., Middaugh, L. D., and Kalivas, P. W. (2006). Development of an alcohol deprivation and escalation effect in C57BL/6J mice. Alcohol. Clin. Exp. Res. 30, 2017-2025. doi: 10.1111/j.1530-0277.2006.00248.x

Mihalak, K. B., Carroll, F. I., and Luetje, C. W. (2006). Varenicline is a partial agonist at alpha4beta2 and a full agonist at alpha7 neuronal nicotinic receptors. Mol. Pharmacol. 70, 801-805. doi: 10.1124/mol.106.025130

Millar, N. S., and Gotti, C. (2009). Diversity of vertebrate nicotinic acetylcholine receptors. Neuropharmacology 56, 237-246. doi: 10.1016/j.neuropharm.2008.07.041

Mineur, Y. S., and Picciotto, M. R. (2008). Genetics of nicotinic acetylcholine receptors: relevance to nicotine addiction. Biochem. Pharmacol. 75, 323-333. doi: 10.1016/j.bcp.2007.06.010

Mitchell, J. M., Teague, C. H., Kayser, A. S., Bartlett, S. E., and Fields, H. L. (2012). Varenicline decreases alcohol consumption in heavy-drinking smokers. Psychopharmacology 223, 299-306. doi: 10.1007/s00213-012-2717-x

Montag, C., Kirsch, P., Sauer, C., Markett, S., and Reuter, M. (2012). The role of the CHRNA4 gene in internet addiction: a case-control study. J. Addict. Med. 6, 191-195. doi: 10.1097/ADM.0b013e31825ba7e7

Moroni, M., and Bermudez, I. (2006). Stoichiometry and pharmacology of two human alpha4beta2 nicotinic receptor types. J. Mol. Neurosci. 30, 95-106. doi: 10.1385/JMN:30:1:95

Munafo, M. R., Johnstone, E. C., Walther, D., Uhl, G. R., Murphy, M. F., and Aveyard, P. (2011). CHRNA3 rs1051730 genotype and short-term smoking cessation. Nic. Tob. Res. 13, 982-988. doi: 10.1093/ntr/ntr106

Nelson, M. E., Kuryatov, A., Choi, C. H., and Zhou, Y., Lindstrom, J. (2003). Alternate stoichiometries of alpha4beta2 nicotinic acetylcholine receptors. $\mathrm{Mol}$. Pharmacol. 63, 332-341. doi: 10.1124/mol.63.2.332

Neugebauer, N. M., Zhang, Z., Crooks, P. A., Dwoskin, L. P., and Bardo, M. T. (2006). Effect of a novel nicotinic receptor antagonist, $\mathrm{N}, \mathrm{N}^{\prime}$-dodecane1,12-diyl-bis-3-picolinium dibromide, on nicotine self-administration and hyperactivity in rats. Psychopharmacology 184, 426-434. doi: 10.1007/s00213005-0163-8

Niccols, A. (2007). Fetal alcohol syndrome and the developing socio-emotional brain. Brain Cogn. 65, 135-142. doi: 10.1016/j.bandc.2007.02.009

Noël, X., Brevers, D., and Bechara, A. (2013). A neurocognitive approach to understanding the neurobiology of addiction. Curr. Opin. Neurobiol. 23, 632-638. doi: 10.1016/j.conb.2013.01.018 
Paterson, D., and Nordberg, A. (2000). Neuronal nicotinic receptors in the human brain. Prog. Neurobiol. 61, 75-111. doi: 10.1016/S0301-0082(99)00045-3

Perry, D. C., Xiao, Y., Nguyen, H. N., Musachio, J. L., Dávila-García, M. I., and Kellar, K. J. (2002). Measuring nicotinic receptors with characteristics of $\alpha 4 \beta 2$, $\alpha 3 \beta 2$ and $\alpha 3 \beta 4$ subtypes in rat tissues by autoradiography. J Neurochem. 82, 468-481. doi: 10.1046/j.1471-4159.2002.00951.x

Picciotto, M. R., Zoli, M., Lena, C., Bessis, A., Lallemand, Y., Le Novere, N., et al. (1995). Abnormal avoidance learning in mice lacking functional high-affinity nicotine receptor in the brain. Nature 374, 65-67. doi: 10.1038/374065a0

Picciotto, M. R., Zoli, M., Rimondini, R., Lena, C., Marubio, L. M., Pich, E. M., et al. (1998). Acetylcholine receptors containing the beta2 subunit are involved in the reinforcing properties of nicotine. Nature 391, 173-177. doi: 10.1038/34413

Plebani, J. G., Lynch, K. G., Yu, Q., Pettinati, H. M., O’Brien, C. P., and Kampman, K. M. (2012). Results of an initial clinical trial of varenicline for the treatment of cocaine dependence. Drug Alcohol Depend. 121, 163-166. doi: 10.1016/j.drugalcdep.2011.08.025

Quick, M. W., and Lester, R. A. J. (2002). Desensitization of neuronal nicotinic receptors. J. Neurobiol. 53, 457-478. doi: 10.1002/neu.10109

Rahman, S. (2013). Nicotinic receptors as therapeutic targets for drug addictive disorders. CNS Neurol. Dis. Drug Targets 12, 633-640. doi: $10.2174 / 1871527311312050011$

Rahman, S., Neugebauer, N. M., Zhang, Z., Crooks, P. A., Dwoskin, L. P., and Bardo, M. T. (2007). The effects of novel N,N-dodecane-1,12-diyl-bis-3-picolinium dibromide on acute and repeated nicotine-induced increases in extracellular dopamine response in rat nucleus accumbens. Neuropharmacology 52, 755-763. doi: 10.1016/j.neuropharm.2006.09.012

Rahman, S., and Prendergast, M. A. (2012). Brain cholinergic receptor system as a target for treating alcohol dependence. Recent Pat. CNS Drug Discov. 7, 145-150. doi: $10.2174 / 157488912800673173$

Reus, V. I., Obach, R. S., Coe, J. W., Faessel, H., Rollema, H., Watsky, E., et al. (2007). Varenicline: new treatment with efficacy in smoking cessation. Drugs Today 43, 65-75. doi: 10.1358/dot.2007.43.2.1069956

Rezvani, A. H., Cauley, M., Xiao, Y., Kellar, K. J., and Levin, E. D. (2013). Effects of chronic sazetidine-A, a selective $\alpha 4 \beta 2$ neuronal nicotinic acetylcholine receptors desensitizing agent on pharmacologically-induced impaired attention in rats. Psychopharmacology 226, 35-43. doi: 10.1007/s00213-012-2895-6

Rezvani, A. H., Slade, S., Wells, C., Petro, A., Lumeng, L., Li, T.-K., et al. (2010). Effects of sazetidine-A a selective alpha4beta2 nicotinic acetylcholine receptor desensitizing agent on alcohol and nicotine self-administration in selectively bred alcohol-preferring (P) rats. Psychopharmacology 211, 161-174. doi: 10.1007/s00213-010-1878-8

Rice, J. P., Hartz, S. M., Agrawal, A., Almasy, L., Bennett, S., Breslau, N., et al. (2012). CHRNB3 is more strongly associated with Fagerstrom test for cigarette dependence-based nicotine dependence than cigarettes per day: phenotype definition changes genome-wide association studies results. Addiction 107, 2019-2028. doi: 10.1111/j.1360-0443.2012.03922.x

Rodd, Z. A., Bell, R. L., Sable, H. J. K., Murphy, J. M., and McBride, W. J. (2004). Recent advances in animal models of alcohol craving and relapse. Pharmacol. Biochem. Behav. 79, 439-450. doi: 10.1016/j.pbb.2004.08.018

Rollema, H., Coe, J. W., Chambers, L. K., Hurst, R. S., Stahl, S. M., and Williams, K. E. (2007). Rationale, pharmacology and clinical efficacy of partial agonists of alpha4beta 2 nACh receptors for smoking cessation. Trends Pharmacol. Sci. 28, 316-325. doi: 10.1016/j.tips.2007.05.003

Rollema, H., Shrikhande, A., Ward, K. M., Tingley, F. D. III, Coe, J. W., O’Neill, B. T., et al. (2010). Pre-clinical properties of the alpha4beta2 nicotinic acetylcholine receptor partial agonists varenicline, cytisine and dianicline translate to clinical efficacy for nicotine dependence. Br. J. Pharmacol. 160, 334-345. doi: 10.1111/j.1476-5381.2010.00682.x

Roni, M. A., and Rahman, S. (2014). The effects of lobeline on nicotine withdrawalinduced depression-like behavior in mice. Psychopharmacology 231, 2989-2998. doi: 10.1007/s00213-014-3472-y

Rose, J. E. (2009). New findings on nicotine addiction and treatment. Nebr. Symp. Motiv. 55, 31-141. doi: 10.1007/978-0-387-78748-0_8

Ross, S. A., Wong, J. Y., Clifford, J. J., Kinsella, A., Massalas, J. S., Horne, M. K., et al. (2000). Phenotypic characterization of an alpha 4 neuronal nicotinic acetylcholine receptor subunit knock-out mouse. J. Neurosci. 20, 6431-6441.

Sajja, R. K., Dwivedi, C., and Rahman, S. (2010). Nicotinic ligands modulate ethanol-induced Dopamine functions in mice. Pharmacology 86, 168-173. doi: $10.1159 / 000317063$
Sajja, R. K., and Rahman, S. (2011). Lobeline and cytisine reduce voluntary ethanol drinking behavior in male C57BL/6J mice. Prog. Neuropsychopharmacol. Biol. Psychiatry 35, 257-264. doi: 10.1016/j.pnpbp.2010.11.020

Sajja, R. K., and Rahman, S. (2012). Neuronal nicotinic receptor ligands modulate chronic nicotine-induced ethanol consumption in C57BL/6J mice. Pharmacol Biochem Behav. 102, 36-43. doi: 10.1016/j.pbb.2012.03.017

Sajja, R. K., and Rahman, S. (2013a). Nicotinic receptor partial agonists modulate alcohol deprivation effect in C57BL/6J in mice. Pharmacol. Biochem. Behav. 110, 161-167. doi: 10.1016/j.pbb.2013.07.009

Sajja, R. K., and Rahman, S. (2013b). Cytisine modulates chronic voluntary ethanol consumption and ethanol-induced striatal up-regulation of Delta FosB in mice. Alcohol 47, 299-307. doi: 10.1016/j.alcohol.2013.02.003

Salminen, O., Murphy, K. L., McIntosh, J. M., Drago, J., Marks, M. J., Collins, A. C., et al. (2004). Subunit composition and pharmacology of two classes of striatal presynaptic Nicotinic acetylcholine receptors mediating dopamine release in mice. Mol. Pharmacol. 65, 1526-1535. doi: 10.1124/mol.65.6.1526

Santos, N., Chatterjee, S., Henry, A., Holgate, J., and Bartlett, S. E. (2012). The alpha5 neuronal nicotinic acetylcholine receptor subunit plays an important role in the sedative effects of ethanol but does not modulate consumption in mice. Alcohol. Clin. Exp. Res. 37, 655-662. doi: 10.1111/acer.12009

Sarginson, J. E., Killen, J. D., Lazzeroni, L. C., Fortmann, S. P., Ryan, H. S., Schatzberg, A. F., et al. (2011). Markers in the 15q24 nicotinic receptor subunit gene cluster (CHRNA5-A3-B4) predict severity of nicotine addiction and response to smoking cessation therapy. Am. J. Med. Genet. Part B Neuropsychiatr. Genet. 156B, 275-284. doi: 10.1002/ajmg.b.31155

Schnoll, R, A., and Lerman, C. (2006). Current and emerging pharmacotherapies for treating tobacco dependence. Expert Opin. Emerg. Drugs 11, 429-444. doi: 10.1517/14728214.11.3.429

Sherva, R., Kranzler, H. R., Yu, Y., Logue, M. W., Poling, J., Arias, A. J., et al. (2010). Variation in nicotinic acetylcholine receptor genes is associated with multiple substance dependence phenotypes. Neuropsychopharmacology 35, 1921-1931. doi: 10.1038/npp.2010.64

Soderpalm, B., Ericson, M., Olausson, P., Blomqvist, O., and Engel, J. A. (2000). Nicotinic mechanisms involved in the dopamine activating and reinforcing properties of ethanol. Behav. Brain Res. 113, 85-96. doi: 10.1016/S01664328(00)00203-5

Solinas, M., Scherma, M., Fattore, L., Stroik, J., Wertheim, C., Tanda, G., et al. (2007). Nicotinic alpha 7 receptors as a new target for treatment of cannabis abuse. J. Neurosci. 27, 5615-5620. doi: 10.1523/JNEUROSCI.0027-07.2007

Sorice, R., Bione, S., Sansanelli, S., Ulivi, S., Athanasakis, E., Lanzara, C., et al. (2011). Association of a variant in the CHRNA5-A3-B4 gene cluster region to heavy smoking in the Italian population. Eur. J. Hum. Genet. 19, 593-596. doi: 10.1038/ejhg.2010.240

Sotomayor-Zarate, R., Gysling, K., Busto, U. E., Cassels, B. K., Tampier, L., and Quintanilla, M. E. (2013). Varenicline and cytisine: two nicotinic acetylcholine receptor ligands reduce ethanol intake in University of Chile bibulous rats. Psychopharmacology 227, 287-298. doi: 10.1007/s00213-013-2974-3

Spanagel, R., and Hölter, S. M. (1999). Long-term alcohol self-administration with repeated alcohol deprivation phases: an animal model of alcoholism? Alcohol 34, 231-243. doi: 10.1093/alcalc/34.2.231

Sparta, D. R., Ferraro, F. M. III, Fee, J. R., Knapp, D. J., Breese, G. R., and Thiele, T. E. (2009). The alcohol deprivation effect in C57BL/6J mice is observed using operant self-administration procedures and is modulated by CRF-1 receptor signaling. Alcohol. Clin. Exp. Res. 233, 31-42. doi: 10.1111/j.1530-0277.2008. 00808.x

Steensland, P., Simms, J. A., Holgate, J., Richards, J. K., and Bartlett, S. E. (2007). Varenicline, an alpha4beta2 nicotinic acetylcholine receptor partial agonist, selectively decreases ethanol consumption and seeking. Proc. Natl. Acad. Sci. U.S.A. 104, 12518-12523. doi: 10.1073/pnas.0705368104

Tapper, A. R., McKinney, S. L., Nashmi, R., Schwarz, J., Deshpande, P., Labarca, C. et al. (2004). Nicotine activation of alpha $4^{\star}$ receptors: sufficient for reward, tolerance, and sensitization. Science 306, 1029-1032. doi: 10.1126/science.1099420

Tobey, K. M., Walentiny, D. M., Wiley, J. L., Carroll, F. I., Damaj, M. I., Azar, M. R., et al. (2012). Effects of the specific $\alpha 4 \beta 2$ nAChR antagonist, 2-fluoro3-(4-nitrophenyl) deschloroepibatidine, on nicotine reward-related behaviors in rats and mice. Psychopharmacology 223, 159-168. doi: 10.1007/s00213-0122703-3

Toll, L., Zaveri, N. T., Polgar, W. E., Jiang, F., Khroyan, T. V., Zhou, W., et al. (2012). AT-1001: a high affinity and selective $\alpha 3 \beta 4$ nicotinic 
acetylcholine receptor antagonist blocks nicotine self-administration in rats. Neuropsychopharmacology 37, 1367-1376. doi: 10.1038/npp.2011.322

Tuesta, L. M., Fowler, C. D., and Kenny, P. J. (2011). Recent advances in understanding nicotinic receptor signaling mechanisms that regulate drug-self administration behavior. Biochem. Pharmacol. 82, 984-995. doi: 10.1016/j.bcp.2011. 06.026

Tutka, P., and Zatoñski, W. (2006). Cytisine for the treatment of nicotine addiction: from a molecule To therapeutic efficacy. Pharmacol. Rep. 53, 777-798.

Uhl, G. R., Drgonova, J., and Hall, F. S. (2014). Curious cases: altered doseresponse relationships in addiction genetics. Pharmacol. Ther. 141, 335-346. doi: 10.1016/j.pharmthera.2013.10.013

Verrico, C. D., Mahoney, J. J. III, Thompson-Lake, D. G., Bennett, R. S., Newton, T. F., De La Garza, R., et al. (2014). Safety and efficacy of varenicline to reduce positive subjective effects produced by methamphetamine in methamphetamine-dependent volunteers. Int. J. Neuropsychopharmacol. 17, 223-233. doi: 10.1017/S146114571300134X

Volkow, N. D., and Baler, R. D. (2014). Addiction science: Uncovering neurobiological complexity. Neuropharmacology 76(Pt B), 235-249. doi: 10.1016/j.neuropharm.2013.05.007

Volkow, N. D., and Skolnick, P. (2012). New medications for substance use disorders: challenges and opportunities. Neuropsychopharmacology 37, 290-292. doi: 10.1038/npp.2011.84

Wang, S. D., van der Vaart, A., Xu, Q., Senevirante, C., Pomerleau, O. F., Payne, T. J., et al. (2014). Significant associations of CHRNA2 and CHRNA6 with nicotine dependence in European American and African American populations. Hum. Genet. 133, 575-586. doi: 10.1007/s00439-013-1398-9

Wassenaar, C. A., Dong, Q., Wei, Q., Amos, C. I., Spitz, M. R., and Tyndale, R. F. (2011). Relationship between CYP2A6 and CHRNA5-CHRNA3-CHRNB4 variation and smoking behaviors and lung cancer risk. J. Natl. Cancer Inst. 103, 1342-1346. doi: 10.1093/jnci/djr237

Weiss, F., and Porrino, L. J. (2002). Behavioral neurobiology of alcohol addiction: recent advances and challenges. J. Neurosci. 222, 3332-3337. Available online at: http://www.jneurosci.org/content/22/9/3332.long

Wilkie, G. I., Hutson, P. H., Stephens, M. W., Whiting, P., and Wonnacott, S. (1993). Hippocampal Nicotinic autoreceptors modulate acetylcholine release. Biochem. Soc. Trans. 21, 429-431.

Wise, R. A., and Koob, G. F. (2014). The development and maintenance of drug addiction. Neuropsychopharmacology 39, 254-262. doi: 10.1038/npp. 2013.261

Wojas-Krawczyk, K., Krawczyk, P., Biernacka, B., Grzybek, M., Kolodziej, P., Kucharczyk, T., et al. (2012). The polymorphism of the CHRNA5 gene and the strength of nicotine addiction in lung cancer and COPD patients. Eur. J. Cancer Prev. 21, 111-117. doi: 10.1097/CEJ.0b013e32834c9b40

Wonnacott, S., Kaiser, S., Mogg, A., Soliakov, L., and Jones, I. W. (2000). Presynaptic nicotinic Receptors modulating dopamine release in the rat striatum. Eur. J. Pharmacol. 393, 51-58. doi: 10.1016/S0014-2999(00)00005-4

Wooltorton, J. R., Pidoplichko, V. I., Broide, R. S., and Dani, J. A. (2003). Differential desensitization and distribution of nicotinic acetylcholine receptor subtypes in midbrain dopamine areas. J Neurosci. 23, 3176-3185. Available online at: http://www.jneurosci.org/content/23/8/3176.long

Wouda, J. A., Riga, D., De Vries, W., Stegeman, M., van Mourik, Y., Schetters, D., et al. (2011). Varenicline attenuates cue-induced relapse to alcohol but not nicotine seeking while reducing inhibitory response control. Psychopharmacology 216, 267-277. doi: 10.1007/s00213-011-2213-8

Xiao, Y., Fan, H., Musachio, J. L., Wei, Z. L., Chellappan, S. K., Kozikowski, A. P., et al. (2006). Sazetidine-A, a novel ligand that desensitizes $\alpha 4 \beta 2$ nicotinic acetylcholine receptors without activating them. Mol. Pharmacol. 70, 1454-1460. doi: 10.1124/mol.106.027318

Yang, X., Criswell, H. E., and Breese, G. R. (1996). Nicotine-induced inhibition in medial septum Involves activation of presynaptic nicotinic cholinergic receptors on gamma-aminobutyric acid-Containing neurons. J. Pharmacol. Exp. Ther. 276, 482-489.

Young, E. M., Mahler, S., Chi, H., and de Wit, H. (2005). Mecamylamine and ethanol preference in healthy volunteers. Alcohol Clin. Exp. Res. 29, 58-65. doi: 10.1097/01.ALC.0000150007.34702.16

Zachariou, V., Caldarone, B. J., Weathers-Lowin, A., George, T. P., Elsworth, J. D., Roth, R. H., et al. (2001). Nicotine receptor inactivation decreases sensitivity to cocaine. Neuropsychopharmacology, 24, 576-589. doi: 10.1016/S0893133X(00)00224-4

Zanetti, L., de Kerchove D'Exaerde, A., Zanardi, A., Changeux, J. P., Picciotto, M. R., and Zoli, M. (2006). Inhibition of both alpha7 ${ }^{\star}$ and beta $2^{\star}$ nicotinic acetylcholine receptors is necessary to prevent development of sensitization to cocaine-elicited increases in extracellular dopamine levels in the ventral striatum. Psychopharmacology 187, 181-188. doi: 10.1007/s00213-006-0419-y

Zhu, A. Z., Renner, C. C., Hatsukami, D. K., Benowitz, N. L., and Tyndale, R. F. (2013). CHRNA5-A3-B4 genetic variants alter nicotine intake and interact with tobacco use to influence body weight in Alaska Native tobacco users. Addiction 108, 1818-1828. doi: 10.1111/add.12250

Zoli, M., Léna, C., Picciotto, M. R., and Changeux, J. P. (1998). Identification of four classes of brain nicotinic receptors using beta 2 mutant mice. J. Neurosci. $18,4461-4472$.

Zoli, M., Moretti, M., Zanardi, A., McIntosh, J. M., Clementi, F., and Gotti, C. (2002). Identification of the nicotinic receptor subtypes expressed on dopaminergic terminals in the rat striatum. J. Neurosci. 22, 8785-8789. Available online at: http://www.jneurosci.org/content/22/20/8785. long

Conflict of Interest Statement: The authors declare that the research was conducted in the absence of any commercial or financial relationships that could be construed as a potential conflict of interest.

Received: 18 August 2014; accepted: 04 December 2014; published online: 15 January 2015.

Citation: Rahman S, Engleman EA and Bell RL (2015) Nicotinic receptor modulation to treat alcohol and drug dependence. Front. Neurosci. 8:426. doi: 10.3389/fnins. 2014.00426

This article was submitted to Neuropharmacology, a section of the journal Frontiers in Neuroscience.

Copyright (C) 2015 Rahman, Engleman and Bell. This is an open-access article distributed under the terms of the Creative Commons Attribution License (CC BY). The use, distribution or reproduction in other forums is permitted, provided the original author(s) or licensor are credited and that the original publication in this journal is cited, in accordance with accepted academic practice. No use, distribution or reproduction is permitted which does not comply with these terms. 